\title{
Trends in scientific publications in physical education: a multifaceted field?
}

\author{
Jacqueline Leta, Suely Rosa
}

\begin{abstract}
The paper investigates diversity in terms of interest and goals in international research in Physical Education (PE). This investigation is based on publications in PE indexed in three major international databases, namely Medline, Scopus and Web of Science (WoS). To identify these publications in Medline, we searched for "physical education and training". As for the WoS and Scopus, we searched for "physical education" in the title, abstract or key-word. We also searched for "physical education" in the affiliation address only in the Scopus database, which we describe as Scopus-Afill. Using these strategies, we found 2,257 documents in Medline, 6,107 in WoS, 8,807 in Scopus and 5,838 in Scopus - Affil. for the 1991-2005 period. Our findings offer evidence that PE research is mostly associated with biological and medical sciences. However, our results show that the field is multifaceted when it comes to the nature of PE contributions to knowledge.
\end{abstract}

\section{Introduction}

Physical Education (PE) may be considered one of the oldest human activities. Evidence for the practice of physical activities in daily life appears since the ancient Greeks. As widely known, physical exercise for these people was essential for molding the body according to the image of their gods. The Greeks' concept of physical activity as a prerequisite for achieving an ideal body and spirit persisted until the Middle Ages, when the training of the body - and the body as a mode of being and existing - was mortified, degraded, frequently ignored and held as repugnant and repulsive. ${ }^{1}$ These ideas, however, found resistance during the Renaissance, when the practice of physical activities gained renewed importance by the flourishing of Humanism, which revived Greeks' thought and their concept of the body.

Although the association between physical activity and education appeared during the $14^{\text {th }}$ century, implementation of PE as a regular discipline in the formal education system occurred only in 1774, in Germany. The systematization of knowledge in PE was based primarily on information from medicine and natural sciences, especially biological sciences, and also on pedagogical principles. ${ }^{1,2}$ Different systems of gymnastics, such as the German, Swedish and English, were created in Europe in the 1800's. ${ }^{3}$ Each of these models had a different concept of PE. For the Germans, the practice of PE emphasized pedagogical aspects; for the Swedish, the emphasis was on anatomical and physiological aspects. For the English, the focus was on games and sports. All these European models influenced the development of $\mathrm{PE}$ in the US at the beginning of the 1800's, when health started to be increasingly noted as an important issue among North Americans.

These most widely disseminated gymnastics systems from Sweden, Germany and England still influence the way PE is defined and conceived worldwide. The diversity in concepts was pointed out by some specialists such as $\mathrm{Naul}^{3}$ who wrote "across Europe, concepts of physical education are just as diverse as their terminological definitions". For Mechikoff \& Estes " "terms such as gymnastics, physical culture, physical training and physical education were used more or less synonymously to describe the systematic exercise programs that emerged during this time" [referring to the 1800's]. Hence, at present, different concepts and terms - such as kinesiology, sport science, science of human movement and PE - coexist and characterize the field of PE, suggesting multiple interests and goals among their professionals.

As for research in PE, such diversity has been the subject of an intense debate. On the one hand, there is a sense that PE "is a field of study that draws from subject and methods in both the biological and social sciences". 2 On the other hand, the pursuit of a PE research project within the scope of the hard sciences 
seems to add prestige to the project. This dispute for scientific recognition and the scientific habitus of the field seem to reflect a duality in terms of PE research interests. We may assume that PE is a field devoted to biological sciences but also to social sciences and humanities.

Currently, the context of PE research can be understood from a Bourdieusien concept of scientific field. A field is a social arena in which people - researchers - strive to establish domain of a given concept, with greater success attributed to those with the higher levels of social capital (including, for instance, that of academic credentials, such as having studied in important schools) and of scientific capital (including scientific authority - prestige, recognition, celebrity - and visibility of their publications).

Based on this Bourdieusien notion of scientific field and habitus, we have attempted to identify research trends in PE. Our main questions have been the following: What is the state-of-the-art for research in PE? What is the weight of biological sciences for PE research? Do scientific publications in the field reveal multiple interests that may contribute to such a multifaceted profile? What are the main concepts and/or disciplines that have been disseminated by PE scientific communications?

Our first step to address these questions was to look at the Brazilian context. We found that research on biological issues, mainly physiology, predominates among scientific articles published in four Brazilian physical education journals ${ }^{5}$ as well as in publications by authors from 11 Brazilian graduate programs in PE. ${ }^{6}$ In our previous studies, ${ }^{5,6}$ we have also identified a lower number of scientific documents focused on issues in social sciences and humanities, confirming the prevalence of biological and medical issues in PE research.

The present study however focuses on the international scenario. The aims are: to identify the number and type of scientific documents ${ }^{\mathrm{a}}$ in PE retrieved from three international data sources, namely, Medline, Scopus and Web of Science databases, and understand to what extent international research in PE make this a field with multiple interests and aims.

\section{Methods}

Scientific documents in PE were accessed from the databases: Medline, WoS (WoS) and Scopus. Medline is a public domain bibliographic database that is maintained by the US National Library of Medicine. Each Medline record contains a series of bibliographic metadata, including primary and secondary descriptors that characterize the paper's main theme, fields and disciplines. These concepts are manually assigned by skilled librarians or health specialists in the standardized Medical Subject Headings (MeSH) vocabulary. Differently, Scopus and WoS are databases supported and maintained by private organizations, namely Elsevier ${ }^{7}$ and Thomson Reuters. ${ }^{8}$ These databases can be easily accessed from any Brazilian research institute through subscriptions by the Ministry of Education.

International publications in PE were first retrieved from Medline throughout its interface with the Virtual Health Library (VHL). As the retrieval process included a very complex query and a large amount of information, computers at VHL were programmed to run it automatically throughout the night in October 2008. This process was arranged by Mr. Tardelli, the manager of VHL's Information Operation sector. The retrieved information was organized in an Excel archive.

We opted to retrieve documents identified by the term Physical Education and training as the major topic or primary descriptor, as there is no MeSH term named Physical Education. Using this search strategy for the period of 1966-2008, we obtained a total of 5,726 publications, which we assume to describe the bulk of research in PE. For each document, we collected a series of data, but for the present study only information related to publication year, journal title, secondary descriptors and abstract are shown. Based on the MeSH secondary descriptors $(n=1,690)$, we carried out the analysis of the main disciplines. These descriptors were first ordered according to the number of occurrences among 5,726 documents, and those with 10 or fewer occurrences were discarded (a total of 1,481). Then, each of the remaining 209 secondary descriptors was logged into a structured and dynamic vocabulary descriptor, DeCS, in order to identify its core discipline. On the basis of the DeCS classification, we made a list of main disciplines and their respective descriptors. This list was used to identify the descriptors of the 5,726 documents and they were categorized, one by one, and associated with one main discipline that anchored the study. Using this approach, we were able to identify the main discipline in 4,696 documents ( $82 \%$ of the original sample); for 1,030 documents ( $18 \%$ of the original sample), it was not possible to identify a single main discipline, and we decided to exclude them.

In order to complement Medline analysis, we also collected data from other two databases, which have a multidisciplinary coverage, Web of Sceince (WoS) and Scopus. WoS comprises seven different 
databases, especially (1) Science Citation Index Expanded, with over 6,650 major journals, (2) Social Sciences Citation Index, with over 1,950 journals, and (3) Arts \& Humanities Citation Index, which covers 1,160 of the world's leading arts and humanities journals. Scopus' coverage includes around 16,500 peer-reviewed journals related to scientific, technical, medical and social sciences literature including Arts \& Humanities. Note that Scopus covers $100 \%$ of Medline titles.

In order to recover the largest number of documents in PE from these two databases, we used two search approaches: (1) searching the term "physical education" in the title, abstract or key-word within WoS and Scopus and (2) searching the term "physical education" in the affiliation address. This last strategy was carried out only for Scopus and we named it Scopus-Affil. Using these strategies, we obtained a total of 9,493 documents in WoS, 12,512 in Scopus and 7,962 in Scopus -Affil., from the period of 1966-2005. As previously stated these documents were assumed to describe most research in PE.

Due to some inconsistencies in terms of time and address coverage in both Scopus and WoS databases, the present analysis considered trends in PE publications only in recent periods, 1991-1995, 1996-2000 and 2001-2005. Hence, the sum of documents analyzed in the whole period (1991-2005) was 2,257 in Medline, 6,107 in WoS, 8,807 in Scopus and 5,838 Scopus - Affil.

In the case of Scopus and WoS, for each of these periods, all information about journals and their publications were collected directly from the databases. This information is provided automatically from both databases through their on-line interface.

\section{Physical Education research: trends over time}

Following trends over time, we have found a quantitative growth in international publications in PE within the three databases (Figure 1 - columns). For publications retrieved from Medline, we observed a growth of $68 \%$ (from 722 to 1,064) from the first to the last five-year study period. As for WoS, we found a growth of $35 \%$ (from 1,551 to 4,473), while for Scopus, this growth was 51\% (from 1,539 to 2,989), when the term "physical education" was searched in the title, abstract or key-word, and 50\% (from 1,400 to 2,814), when the term "physical education" was searched in the affiliation address.

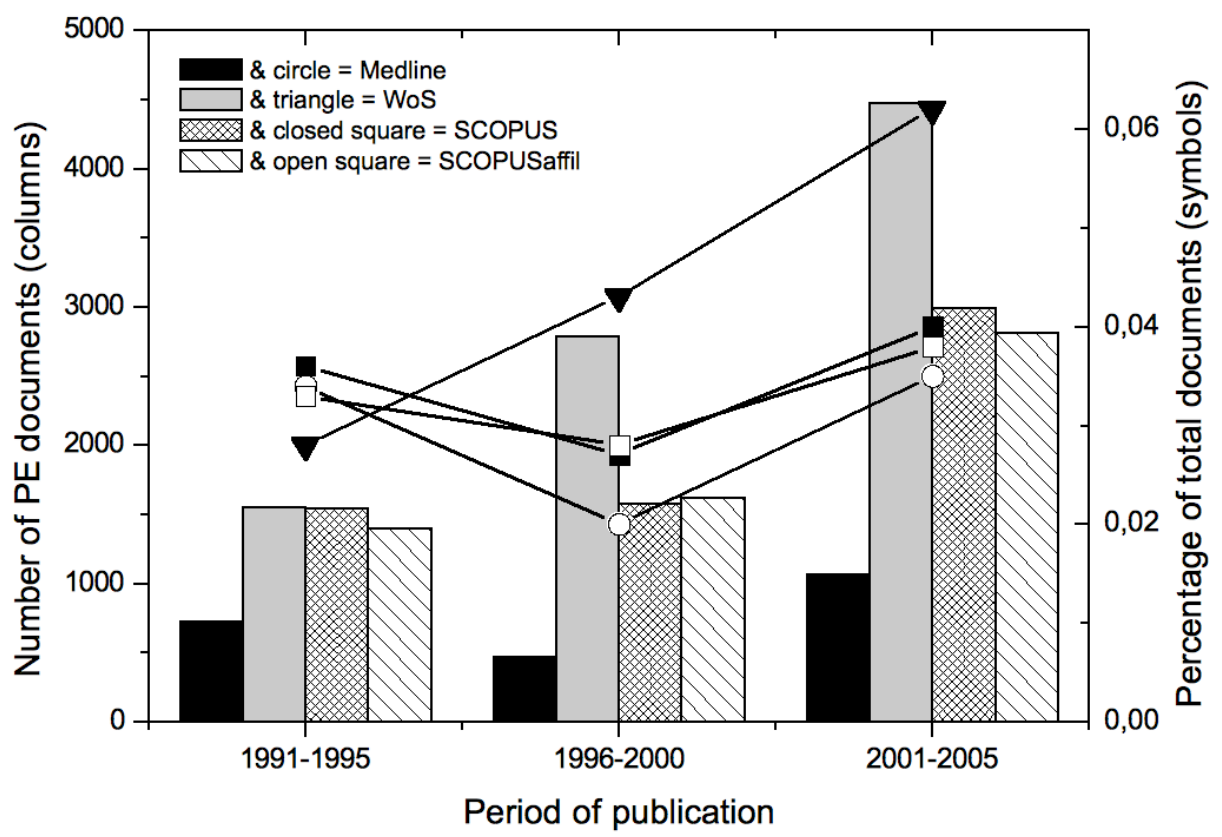

Figure 1. Time trends in number of documents in Physical Education indexed in Medline, Scopus and WoS databases.

As can be noted, the quantitative growth of PE publications did not represent a real growth when expressed as a percentage of total number of publications indexed in Medline and Scopus (Figure 1 - 
lines with symbols), but it did represent a real growth within WoS (see Figure $1-$ line+tringle). In this case, we observed that the share of PE publications was $0.028 \%$ for the whole WoS database in the 19911995 period and it increased to $0.062 \%$ in the $2001-2005$ period. $^{c}$

\section{Physical Education research: main journals}

The first scientific journals appeared in Europe in the 1600's. Since then, the number of scientific journals has increased markedly, reflecting in part an increasing demand from specialized fields. ${ }^{9-11}$ Although the current number of scientific journals is not known with certainty, deSolla Price ${ }^{12}$ in his classical work Little Science, Big Science, estimated that it would reach 1 million by the year 2000. Just a small fraction of such journals is accessible through bibliographic sources. In this sense, databases such as Medline, Scopus and WoS contribute to the dissemination of new knowledge published in this small set of journals.

From a scientometric perspective, a common approach to characterizing a scientific field is to analyze its core journals, which represent any quantity (from one to $n$ ) of journals that concentrate $1 / 3$ of publications (in a defined period) in the field ${ }^{13}$. Knowing this set of journals allows one to recognize some trends for a given field, such as its most frequent topics. Ming-Yueh ${ }^{14}$ and Glänzel, Janssens\&Thijs 15 , for example, have recently carried out scientometric studies through the analysis of core journals for a better understanding of a particular field.

In our study, international publications in PE were also analyzed in terms of core journals (Table 1 and 2). Table 1 lists the number of documents in PE, the number of core journals and the number of documents published by such journals for each period and database. It is easily noted that Medline has the lowest number of core journals (varies from 3 to 6 journals), a fact that may be related to its coverage, focusing on the health sciences. As for the other databases, we found higher numbers of core journals: from 10 to 131 (this points to some inconsistencies, which were not investigated in this study) in WoS and from 6 to 17 in Scopus. This panorama suggests that these databases, which have larger field coverage and a multidisciplinary profile, offer more opportunities to the diffusion of research in PE.

\begin{tabular}{|l|l|l|l|l|}
\hline \multirow{4}{*}{ Medline } & Period & $\begin{array}{l}\text { Number of } \\
\text { documents }\end{array}$ & $\begin{array}{l}\text { Number of core } \\
\text { journals }\end{array}$ & $\begin{array}{l}\text { Number of documents } \\
\text { in the core jounals }\end{array}$ \\
\hline \multirow{3}{*}{ WoS } & $1991-95$ & 722 & 4 & 225 \\
\cline { 2 - 5 } & $1996-00$ & 471 & 6 & 163 \\
\cline { 2 - 5 } & $2001-05$ & 1.064 & 3 & 326 \\
\hline \multirow{3}{*}{ Scopus } & $1991-95$ & 1.536 & 131 & 449 \\
\cline { 2 - 6 } & $1996-00$ & 1.582 & 10 & 517 \\
\cline { 2 - 6 } & $2001-05$ & 2.989 & 15 & 976 \\
\hline \multirow{3}{*}{ Scopus - Affil. } & $1991-95$ & 1.551 & 6 & 505 \\
\cline { 2 - 6 } & $1996-00$ & 2.783 & 10 & 545 \\
\cline { 2 - 6 } & $2001-05$ & 4.473 & 9 & 1.025 \\
\cline { 2 - 6 } & $1991-95$ & 1.400 & 6 & 455 \\
\cline { 2 - 5 } & $2001-05$ & 1.624 & 16 & 939 \\
\hline
\end{tabular}

Table 1. Number of documents and core journals in Physical Education indexed in Medline, Scopus and WoS databases.

Regarding Medline journals that publish reports on research in PE, we observed that journals dedicated to disseminating biological and medical knowledge, especially those dedicated to physiological studies, are the majority among the set of core journals (Table 2). A more careful look at these core journals makes it possible to identify an overlap of journals within the three databases. Accordingly, the journals Perceptual and Motor Skills and Research Quarterly for Exercise \& Sport appear simultaneously in the three databases. The journals Adapted Physical Activity Quarterly, Journal of Teaching in Physical Education, Quest and Sport Education \& Society appear in Scopus and WoS. And all core journals from Medline are also included among core journals in Scopus. 
Whereas we observe a wide spectrum of core journals in the two multidisciplinary databases, WoS and Scopus, we also note a prevalence of journals whose main foci are medical and biological sciences (see titles in bold in Table 2). In Medline 6 out of the 8 core journals illustrate this feature; in WoS, this ratio is 10 out of 18; in Scopus, 9 out of 16, when the search of "physical education" was in the title or abstract, and 15 out of 22, when the search was in the address (Scopus - Affil.).

The other journals (titles not in bold in Table 2) have a more interdisciplinary scope, publishing papers from different disciplines, whether derived from medical and biological sciences or from social sciences and humanities.

\begin{tabular}{|c|c|c|}
\hline & Period & Titles \# \\
\hline \multirow{3}{*}{$\begin{array}{l}\text { M } \\
\text { e } \\
\text { d } \\
\text { l } \\
\text { i } \\
\text { n } \\
\text { e }\end{array}$} & $1991-95$ & $\begin{array}{l}\text { Journal of Applied Physiology (78); Research Quarterly for Exercise and Sport (58); European Journal of } \\
\text { Applied Physiology and Occupational Physiology (52); International Journal of Sports Medicine (37) }\end{array}$ \\
\hline & 1996-00 & $\begin{array}{l}\text { Research Quarterly for Exercise and Sport (43); Medicine and Science in Sports and Exercise (34); Journal of } \\
\text { Applied Physiology (24); Perceptual and Motor Skills (22); European Journal of Applied Physiology and } \\
\text { Occupational Physiology (21); American Journal of Physiology (19) }\end{array}$ \\
\hline & $2001-05$ & $\begin{array}{l}\text { The Journal of Strength \& Conditioning Research (199); Medicine and Science in Sports and Exercise (71); } \\
\text { Research Quarterly for Exercise and Sport (56) }\end{array}$ \\
\hline \multirow{3}{*}{$\begin{array}{l}\text { W } \\
\mathbf{o} \\
\mathbf{S}\end{array}$} & $1991-95$ & $\begin{array}{l}\text { Physical Therapy (25); Quest (14); Research Quarterly for Exercise and Sport (14); International Review of } \\
\text { Education (12); Perceptual and Motor Skills (8) }\end{array}$ \\
\hline & $1996-00$ & $\begin{array}{l}\text { Journal of Teaching in Physical Education (100); Archives of Physical Medicine and Rehabilitation (82); } \\
\text { Research Quarterly for Exercise and Sport (81); Quest (70); Physical Therapy (37); Preventive Medicine (36); } \\
\text { Perceptual and Motor Skills (32); Adapted Physical Activity Quarterly (29); Journal of the American Geriatrics } \\
\text { Society (27); American Journal of Epidemiology (23) }\end{array}$ \\
\hline & $2001-05$ & $\begin{array}{l}\text { Research Quarterly for Exercise and Sport (277); Journal of teaching in Physical Education (94); Journal of } \\
\text { teaching in Physical Education (100); Archives of Physical Medicine and Rehabilitation (78); Perceptual and } \\
\text { Motor Skills (57); Preventive Medicine (54); Sport education and society (53); Quest (52); International Journal } \\
\text { of Obesity (49); Social Science \& Medicine (48); Pediatrics (42); Journal of the American Geriatrics Society } \\
\text { (39); Adapted Physical Activity Quarterly (36); American Journal of Preventive Medicine (33); European } \\
\text { Journal of Clinical Nutrition (32); Journal of American Dietetic Association (32) }\end{array}$ \\
\hline \multirow{3}{*}{$\begin{array}{l}\text { S } \\
\mathbf{c} \\
\mathbf{0} \\
\mathbf{p}\end{array}$} & $1991-95$ & $\begin{array}{l}\text { Journal of Applied Physiology (107); Medicine and Science in Sports and Exercise (106); European Journal of } \\
\text { Applied Physiology and Occupational Physiology (90); Research Quarterly for Exercise and Sport (81); } \\
\text { International Journal of Sports Medicine (71); Journal of Sports Sciences (50) }\end{array}$ \\
\hline & 1996-00 & $\begin{array}{l}\text { Quest (113); Journal of Teaching in Physical Education (75); Medicine and Science in Sports and Exercise (71); } \\
\text { Research Quarterly for Exercise and Sport (55); Perceptual and Motor Skills (54); Sport Education and Society (40); } \\
\text { European Journal of Applied Physiology and Occupational Physiology (37); Sports Medicine (35); } \\
\text { International Journal of Sports Medicine (33); Adapted Physical Activity Quarterly (32) }\end{array}$ \\
\hline & $2001-05$ & $\begin{array}{l}\text { Journal of Strength and Conditioning Research (247); Research Quarterly for Exercise and Sport (151); } \\
\text { Medicine and Science in Sports and Exercise (124); Quest (120); International Journal of Sports } \\
\text { Medicine (79); British Journal of Sports Medicine (77); Journal of Teaching in Physical Education (76); } \\
\text { European Journal of Applied Physiology (76); Chinese Journal of Clinical Rehabilitation (75) }\end{array}$ \\
\hline \multirow{3}{*}{$\begin{array}{l}\text { S } \\
\mathbf{c} \\
\mathbf{o} \\
\mathbf{p} \\
\mathbf{u} \\
\mathbf{s} \\
- \\
\mathbf{A} \\
\mathbf{f} \\
\mathbf{f} \\
\mathbf{i} \\
\mathbf{l}\end{array}$} & $1991-95$ & $\begin{array}{l}\text { Journal of Sports Sciences (112); Perceptual and Motor Skills (99); Research Quarterly for Exercise and Sport (78); } \\
\text { Medicine and Science in Sports and Exercise (60); Adapted Physical Activity Quarterly (54); Journal of Sports } \\
\text { Medicine and Physical Fitness (52) }\end{array}$ \\
\hline & 1996-00 & $\begin{array}{l}\text { Perceptual and Motor Skills (60); Journal of Sports Sciences (48); European Journal of Applied Physiology and } \\
\text { Occupational Physiology (43); Biology of Sport (38); Journal of Human Movement Studies (37); Quest (36); } \\
\text { Medicine and Science in Sports and Exercise (36); Journal of Athletic Training (36); Research Quarterly for } \\
\text { Exercise and Sport (33); Journal of Applied Physiology (27); Journal of Strength and Conditioning } \\
\text { Research (26); Journal of Teaching in Physical Education (25); Adapted Physical Activity Quarterly (23); Journal } \\
\text { of Sports Medicine and Physical Fitness (22); Journal of Aging and Physical Activity (22); International } \\
\text { Journal of Sports Medicine (21) }\end{array}$ \\
\hline & $2001-05$ & $\begin{array}{l}\text { Chinese Journal of Clinical Rehabilitation (244); Perceptual and Motor Skills (71); Medicine and Science in } \\
\text { Sports and Exercise (64); European Journal of Applied Physiology (57); Journal of Strength and } \\
\text { Conditioning Research (55); Biology of Sport (54); Journal of Applied Physiology (54); Journal of Sports } \\
\text { Medicine and Physical Fitness (51); Journal of Human Movement Studies (50); Research Quarterly for Exercise } \\
\text { and Sport (44); Adapted Physical Activity Quarterly (34); Journal of Teaching in Physical Education (31); Revista } \\
\text { Brasileira de Medicina do Esporte (31); British Journal of Sports Medicine (30); Journal of Sports Science } \\
\text { and Medicine (24); Pediatric Exercise Science (23); Journal of Sports Sciences (22) }\end{array}$ \\
\hline \multicolumn{3}{|c|}{$\begin{array}{l}\text { Note 1: Titles in bold represent journals whose main scope is to publish studies constituted of knowledge from medical and } \\
\text { biological sciences. } \\
\text { Note 2: Numbers in parentheses represent the total number of documents in each journal. } \\
\text { Note 3: An association between the total number of journals listed in Table } 1 \text { and their titles in Table } 2 \text { shows some duplication of } \\
\text { journals. Hence, the sum of core journals, excluding this redundancy, is } 8 \text { for Medline, } 18 \text { for WoS, } 16 \text { for Scopus and } 22 \\
\text { for Scopus-Affil. }\end{array}$} \\
\hline
\end{tabular}

Table 2. List of core journals in Physical Education. 


\section{Physical Education research: main disciplines}

As found in our previous studies dealing with Brazilian research in $\mathrm{PE}{ }^{5,6}$, international research in PE indexed in Medline, WoS and Scopus databases also seems to be directed towards biological and medical sciences. Table 3 lists the most representative disciplines with publications in PE. The list includes only disciplines in which publications sum up 5\% or more in the respective period for each database. The majority is related to knowledge derived from medical and biological sciences. For Medline and Scopus this trend is clear. For the former, it is observed that physiology prevails. Considering the total number of PE publications in each period (see Table 1), those classified as physiology represent $45 \%, 44 \%$ and $51 \%$ in the three studied periods, respectively. As for Scopus, medicine prevails and publications classified under that category represent $84 \%, 73 \%$ and $79 \%$ of the total number (see totals in Table 1 ) in the three studied periods, respectively.

\begin{tabular}{|c|c|c|c|}
\hline \multirow{6}{*}{$\begin{array}{l}\mathbf{M} \\
\mathrm{e} \\
\mathbf{d} \\
\mathbf{l} \\
\mathrm{n} \\
\mathrm{e}\end{array}$} & Fields 1991-95 & Fields 1996-00 & Fields 2001-05 \\
\hline & Physiology (325) & Physiology (208) & Physiology (547) \\
\hline & Psychology (85) & Psychology (50) & Psychology (129) \\
\hline & Biochemistry (67) & Biochemistry (42) & Anatomy (87) \\
\hline & Anatomy (61) & Anatomy (32) & Biochemistry (65) \\
\hline & Education (39) & Medicine (25) & \\
\hline \multirow{10}{*}{$\begin{array}{l}\text { W } \\
\mathbf{0} \\
\mathbf{S}\end{array}$} & Fields 1991-95 & Fields 1996-00 & Fields 2001-05 \\
\hline & Sport Sc. (347) & Sport Sc. (579) & Sport Sc. (945) \\
\hline & Education (272) & $\begin{array}{l}\text { Public, Environ.\& } \\
\text { Occupational Health (428) }\end{array}$ & $\begin{array}{l}\text { Public, Environ.\& Occupational } \\
\text { Health (685) }\end{array}$ \\
\hline & $\begin{array}{l}\text { Public, Environ. \& Occupational } \\
\text { Health (221) }\end{array}$ & Education (308) & Psychology (408) \\
\hline & Med., General \& Internal (157) & Rehabilitation (273) & $\begin{array}{l}\text { Hospitality, Leisure, Sport \& } \\
\text { Tourism (398) }\end{array}$ \\
\hline & Rehabilitation (115) & Med., General \& Internal (235) & Education (379) \\
\hline & Psychology (107) & Psychology (149) & Med., General \& Internal (345) \\
\hline & $\begin{array}{l}\text { Hospitality, Leisure, Sport \& } \\
\text { Tourism (99) }\end{array}$ & & Applied Psychology (341) \\
\hline & Applied Psychology (94) & & Rehabilitation (295) \\
\hline & & & Nutrition \& Dietetics (266) \\
\hline \multirow{4}{*}{$\begin{array}{l}\mathbf{S} \\
\mathbf{c} \\
\mathbf{c} \\
\mathbf{p} \\
\mathbf{u} \\
\mathbf{s}\end{array}$} & Fields 1991-95 & Fields 1996-00 & Fields 2001-05 \\
\hline & Medicine $(1,289)$ & Medicine $(1,158)$ & Medicine $(2,351)$ \\
\hline & Health Professions (645) & Health Professions (596) & Health Professions $(1,474)$ \\
\hline & $\begin{array}{l}\text { Bioch, Genetics and Molecular } \\
\text { Biology (371) }\end{array}$ & Social Sciences (311) & Social Sciences (424) \\
\hline
\end{tabular}




\begin{tabular}{|c|c|c|c|}
\hline & \multirow[t]{2}{*}{ Psychology (174) } & $\begin{array}{l}\text { Bioch, Genetics and Molecular } \\
\text { Biology (257) }\end{array}$ & $\begin{array}{l}\text { Bioch, Genetics and Molecular } \\
\text { Biology (357) }\end{array}$ \\
\hline & & Psychology (174) & Psychology (353) \\
\hline \multirow{7}{*}{$\begin{array}{l}\text { S } \\
\text { c } \\
\text { o } \\
\text { p } \\
\text { u } \\
\text { S } \\
- \\
\text { A } \\
\text { f } \\
\text { f } \\
\text { i } \\
\text { l. }\end{array}$} & Fields 1991-95 & Fields 1996-00 & Fields 2001-05 \\
\hline & Medicine $(1,003)$ & Health Professions (625) & Medicine $(1,984)$ \\
\hline & Health Professions (551) & $\begin{array}{l}\text { Bioch, Genetics and Molecular } \\
\text { Biology (362) }\end{array}$ & Health Professions (920) \\
\hline & $\begin{array}{l}\text { Bioch, Genetics and Molecular } \\
\text { Biology (268) }\end{array}$ & Psychology (251) & $\begin{array}{l}\text { Bioch, Genetics and Molecular } \\
\text { Biology (551) }\end{array}$ \\
\hline & Psychology (268) & Social Sciences (167) & Psychology (373) \\
\hline & Social Sciences $(80)$ & Neuroscience (91) & Social Sciences (245) \\
\hline & & & Neuroscience (157) \\
\hline
\end{tabular}

Note: Numbers in parentheses represent the total number of documents in each main field.

Table 3. Main fields of Physical Education documents.

A different picture is found for publications in WoS. Sports Science predominates, and publications classified under this discipline represent around $20 \%$ of PE total publications indexed in the database (see totals in Table 1). Aiming to clarify the scope of Sports Science, we searched its definition in WoS, which includes publications of "the Applied Physiology of human performance, fitness for participation in sports, nutrition directed toward the prevention and sports performance treatment of injuries and illnesses related to sports. This category also includes publications in psychology and sociology of sport". So even if this discipline is categorized as multidisciplinary, there is a strong bias in the coverage of its journals, which, in WoS, are mainly focused on the medical and biological sciences.

In Table 3 the influence of other disciplines on PE scientific publications can be noted. In Medline, Education and Psychology appear among the disciplines with 5\% or more of representativeness. In WoS, besides these two disciplines, others such as Hospitality, Leisure, Sport \& Tourism are also included. In Scopus, besides Psychology, the Social Sciences is also present.

\section{Discussion}

Our findings show evidence that the approach to PE research in international publications has a strong influence of biological and medical sciences. However, it is important to point out that this study looks at a particular aspect of research in this field: the academic and scientific communication published in the international arena and accessed through different criteria (field and address) for three different databases. Hence, the scope of our analysis is limited. Yet, our findings provide an overview of research and publication trends in PE when it comes to formal communications. The number of documents in PE published in journals indexed in Medline, WoS and Scopus has increased considerably. Nevertheless, such growth did not represent a real input when compared to the totals of each databases; the exception was publications indexed in WoS.

The results observed for major fields (Table 3) are in accordance with our previous data. Our analysis of Brazilian journals indicated that physiology is predominant among articles published in four national PE journals. ${ }^{5}$ The same was found for documents published by authors affiliated with 11 Brazilian graduate programs in PE. ${ }^{6}$ The current results also corroborate the study of Yaman \& Atay, ${ }^{16}$ who analyzed PhD theses in Turkish sports sciences. The authors found that $86.3 \%$ of theses were from health sciences institutes, whereas only $10 \%$ originated from social sciences institutes. 
Our results also show that international research in PE receives contributions from different areas of biology but these are at a lower level when we compared to contributions from non-biological fields. Research in the latter seems to have less prestige and visibility than research in the former. This trend may be explained by the historical context of PE. The main concepts, practices and ideas from biological sciences have been consolidated and incorporated into the ethos of the PE field. This is in accordance with Bourdieu's concept of habitus. Thus, the weight of biology in PE publications seems to drive the field's habitus and its research orientation and interest.

Our data for documents retrieved from Medline, WoS and Scopus databases suggests that PE is a multifaceted research field, which corroborates our initial hypothesis that this field is diverse when it comes to the nature of its contributions to knowledge. Research in PE, analyzed through formal scientific communications, appears to be anchored in several disciplines, which is a remarkable feature of this field of knowledge.

This particular feature seems to be relevant to current discussions ${ }^{3,17-19}$ about the scope and nature of PE and can give some insight into the dynamics of knowledge production in this area.

\section{Acknowledgments}

The authors thank Adalberto O. Tardelli (BIREME/OPAS/OMS) for data retrieval, Dr. Martha Sorenson (IBqM - UFRJ) for comments on earlier versions of the manuscript and Dr. Sonia Vasconcelos (IBqM UFRJ) for comments and revision of the manuscript.

\section{Note and references}

1 R.A. Mechikoff and S.G. Estes (1998), A history and philosophy of sport and physical education: from ancient civilizations to the modern world, Boston, McGraw-Hill.

2 R. Park (1989), The second 100 years: or, can physical education become the Renaissance field of the $21^{\text {st }}$ century? Quest 41(1): 1-27.

3 R. Naul (2003), Concepts of physical education in Europe, in K. Hardman (Ed.), Physical Education: Deconstruction and Reconstruction: issues and directions (pp. 35-52), Schorndorf Hofmann, (accessed at: http://www.wgi.de/meida/Ppdf/Concepts of Physical education in Europe 571115.pdf in September, 29, 2008)

4 P. Bourdieu (1983), Le champ scientifique. Actes de la recherche en sciences sociales, In R. Ortiz. Pierre Bourdieu: Sociologia (pp. 122-155). São Paulo, Ática.

5 S. Rosa and J. Leta (2010), Tendências atuais da pesquisa brasileira em educação física. Parte 1: Uma análise a partir de periódicos nacionais, Revista Brasileira de Educação Física e Esporte 4(1): 121-34.

6 S. Rosa and J. Leta (2011), Tendências atuais da pesquisa brasileira em educação fisica. Parte 2: A heterogeneidade epistemológica nos Programas de Pós-Graduação, Revista Brasileira de Educação Física e Esporte 25 (1) 7-18.

7 ELSEVIER, SCOPUS, http://www.scopus.com/home.url.

8 THOMSON REUTERS. ISI - Web of Science, http://apps.isiknowledge.com/WOS GeneralSearch input.do?highlighted tab=WOS\&product=WOS \&last_prod=WOS\&SID=3EAkOCB1@3dDMFAfnŌm\&search_mode=GeneralSearch.

9 A.J. Meadows (1974), Communication in science. Butterworth \& Co Ltd: London.

10 G. Page, R.Campbell and A.J. Meadows (1997), Journal Publishing, Cambridge University Press, Cambridge.

11 E.H. Fredriksson (2001), A Century of Science Publishing, IOS Press: Amsterdam \& Washington, DC.

12 J.D. deSolla Price (1963), Little science, big science, Columbia Univ. Press, New York.

13 S.C. Bradford (1934), Sources of information on specific subjects, Engineering 26: 85-86.

14 T. Ming-Yueh (2008), A bibliometric analysis of hydrogen energy literature, 1965-2005, Scientometrics 75 (3): 421-438.

15 W. Glänzel, F. Janssens and B. Thijs (2009), A comparative analysis of publication activity and citation impact based on the core literature in bioinformatics, Scientometrics 79(1): 109-129.

16 H. Yaman \& E. Atay (2007), PhD theses in Turkish sports sciences: A study covering the years 19882002. Scientometrics 71(3): 415-421. 
17 A.R.Reppold Filho (2000), In Search of Academic Identity: Physical Education, Sport Science and the Field of Human Movement Studies, doctoral thesis at University of Leeds, LEEDS, England. Available at: http://www.lume.ufrgs.br/bitstream/handle/10183/2691/000280467.pdf? sequence=1

${ }^{18}$ C.P. da Rocha Junior (2005) A Organização do Campo da Educação Física: Considerações sobre o debate, Arquivos em Movimento 1(2): 69-78. Available at:

http://b200.nce.ufrj.br/ revista/artigos/v1n2/artigo07_v1n2.pdf.

${ }^{19}$ R. Rikli (2006), Kinesiology - A “homeless" field: Addressing organization and leadership needs, Quest 58: 288-309.

a The word "publication (s)"is used to describe any piece published in academic journals. The word "document (s)" also refers to any piece published, and both terms are used interchangeably.

b Virtual Health Library is an Brazilian on-line Library in Health Issues, available at: http://regional.bvsalud.org/php/index.php?lang=en

c Percentages were calculated using the following data for 1991-95, 1996-00 and 2001-05: Medline 2,115,754; 2,392,364 and 3,025,853; WoS 5,575,926; 6,535,440 and 7,248,621; Scopus 4,262,895; $5,848,460$ and 7,451,008. The search was performed at February $2^{\text {nd }}, 2012$. Medline totals were collected through PubMed's interface advanced search, which is available at http://www.ncbi.nlm.nih.gov/pubmed/advanced.

\section{Authors}

J. Leta is an associate professor at Federal University of Rio de Janeiro, Brazil. Since 1995, she has been carrying out a series of studies on Bibliometrics, mostly focused on Brazilian scientific publications.

E-mail: jleta@bioqmed.ufr.br.

S. Rosa has a Bachelor in Physical Education, and this paper is part of her $\mathrm{PhD}$ thesis.

E-mail: suely_pereira_rosa@globo.com.

How TO CITE: J. Leta, S. Rosa, Trends in scientific publications in physical education: a multifaceted field?, Jcom 11(01) (2012) A03. 